University of Wollongong

Research Online

Faculty of Business - Papers (Archive)

Faculty of Business and Law

$1-1-2013$

Capital structure and stock returns: Evidence from an emerging market with unique financing arrangements

Khamis Al-Yahyaee

Sultan Qaboos University

Toan Pham

University of New South Wales

Terry S. Walter

University of Technology Sydney, twalter@uow.edu.au

Follow this and additional works at: https://ro.uow.edu.au/buspapers

Part of the Business Commons

Research Online is the open access institutional repository for the University of Wollongong. For further information contact the UOW Library: research-pubs@uow.edu.au 


\title{
Capital structure and stock returns: Evidence from an emerging market with unique financing arrangements
}

\author{
Abstract \\ We investigate capital structure dynamics in a unique financing environment where (1) we avoid the \\ complex tax environments faced by previous studies and where (2) firms rely primarily on bank loans \\ rather than the public debt market.Consistent with recent empirical evidence, we find that stock returns \\ are a first-order determinant of capital structure. Firms show some tendency to rebalance towards their \\ target capital structure. However, the impact of stock returns dominates the effects of rebalancing. We \\ also find that firm's stock returns induce some corporate issuing activity, and managers use issuing \\ activity to counteract some of the mechanistic effects of stock returns. \\ Disciplines \\ Business

\section{Publication Details} \\ Al-Yahyaee, K., Pham, T. \& Walter, T. (2013). Capital structure and stock returns: Evidence from an \\ emerging market with unique financing arrangements. Applied Financial Economics, 23 (14), 1197-1203.
}




\title{
Capital Structure and Stock Returns: Evidence from an Emerging Market with Unique Financing Arrangements
}

\author{
Khamis H. Al-Yahyaee ${ }^{\mathrm{a}}$ \\ Sultan Qaboos University \\ Toan M. Pham ${ }^{\mathrm{b}, *}$ \\ University of New South Wales \\ Terry S. Walter ${ }^{\mathrm{c}}$ \\ University of Technology Sydney
}

${ }^{a}$ Department of Economics and Finance, College of Economics and Political Science, Sultan Qaboos
University, Sultanate of Oman
${ }^{b}$ School of Risk and Actuarial Studies, Australian School of Business, University of New South Wales,
Australia
${ }^{c}$ School of Finance and Economics, University of Technology Sydney, Australia

\begin{abstract}
We investigate capital structure dynamics in a unique financing environment where (1) we avoid the complex tax environments faced by previous studies; and where (2) firms rely primarily on bank loans rather than the public debt market.

Consistent with recent empirical evidence, we find stock returns are a first order determinant of capital structure. Firms show some tendency to rebalance towards their target capital structure. However, the impact of stock returns dominates the effects of rebalancing. We also find that firm's stock returns induce some corporate issuing activity and managers use issuing activity to counteract some of the mechanistic effect of stock returns.
\end{abstract}

Keywords: Oman, capital structure dynamics, stock returns, issuing activity, bank debt.

\section{JEL Classification: G32}

*Corresponding author. E-mail: t.pham@unsw.edu.au

Email addresses: yahyai@squ.edu.om (Khamis H. Al-Yahyaee), t.pham@unsw.edu.au (Toan M. Pham), terry.walter@uts.edu.au (Terry S. Walter). 


\section{Introduction}

Capital structure decisions are enigmatic. There is a surprising lack of consensus even about the basic empirical facts regarding capital structure decisions. This led Myers (1984) to coin the phrase "the capital structure puzzle" and raised a number of unanswered questions. While much research has been conducted since 1984, many of Myers' questions remain unresolved. In an influential and controversial paper, Welch (2004) provides US evidence on Myers questions. For instance, Welch (2004) finds that firms are basically inert and their capital structure changes are mainly caused by their stock returns. Moreover, he documents that firms do not issue debt or equity to counter the effect of stock returns on their capital structure. Welch also shows that after controlling for stock return effects, many previously used proxies play a minor role in explaining capital structure dynamics. But how general is this so-called inertia theory? Are the Welch results general or are they unique to a US institutional setting? Our main objective in this paper is to examine whether stock returns are an important factor in firms capital structure choices in a different market to the US, namely Oman.

There are several institutional factors that differentiate the US from Oman. First, in Oman banks play a pivotal role in financing firms listed on the Muscat Securities Market (MSM), whereas US firms rely more on the public debt market. Second, due to the simplicity of the tax system, Oman provides an "interesting laboratory" to test financial theories. In Oman there are neither personal income taxes nor taxes on investment income such as dividends and capital gains. Specifically firms are taxed at a flat rate of $12 \%$ and individuals are not taxed at all.

Our results show that Omani firms have high leverage ratios and the main source of debt is short-term bank financing. The limited bond market leaves room for banks to 
play an important role in financing Omani firms. Banks mainly provide short-term loans and this explains the high reliance of Omani firms on short-term borrowing.

We also find robust evidence that stock price changes have a strong and primary effect on observed market-based debt ratios. Firms' capital structures seem to move in line with that mechanistically induced by their stock returns. We also find that firms show some tendency to revert to their previous debt ratios. However, the impact of stock returns dominates the effects of readjustment.

The remainder of the paper proceeds as follows. Section II describes the data and presents the measures that we construct to estimate the impact of stock returns on capital structure dynamics. Section III develops the regression specification, presents and examines the estimation results. Section IV concludes the paper.

\section{Data and Methodology}

\section{A. Data}

The data for this study are taken from "Share-Holding Guide of MSM Listed Companies" published by the MSM. The MSM collects annual financial statements and stock price data for all firms listed on MSM. The MSM maintains a website that provides information and financial data related to the performance of listed firms. Each year MSM publishes a book "Share-Holding Guide of MSM Listed Companies" which contains accounting information from financial statements as well as stock return and ownership structure data. We complement the data from the MSM Guide with the MSM index which we obtain from the MSM.

The data set comprise all publicly traded firms listed on the MSM in the four industry sectors that comprise the MSM namely, financial and banking sector, service sector, industry sector, and insurance sector. These sectors contain firms from various industries including hotels, poultry, leasing, fisheries, oil, agriculture, energy, power, 
aviation, banks, investment firms, and manufacturing firms. The data are time series cross-sectional variables which are collected over the entire life of the MSM from 1989 to 2003 .

Any observations with missing data for the book value of debt, and/or market value of equity are deleted because these variables are required to calculate our dependent and independent variables. Because our regression specification includes lagged variables, we also exclude any firm with fewer than two consecutive years of data. The number of firms included in the study changes from one year to another, with a range from 60 to 142. The final data set is an unbalanced panel containing 1,263 firm-year observations.

\section{B. Empirical Model}

Our research question is whether variation in market leverage ratio is caused primarily by stock returns or deliberate managerial choices to adjust to their past target debt ratios. The basic empirical model is a time series cross sectional regression of firms' debt ratios against the lagged market leverage ratio and the stock return induced changes in market value of equity. This estimating equation extends the model used by Welch (2004) to Oman. As with previous studies, the dependent variable in our regressions is market leverage ratio or as Welch calls it the Actual Debt Ratio $\left(\mathrm{ADR}_{\mathrm{t}}\right)$. We define accounting measures in accordance with Welch (2004). Specifically, ADR is defined as the ratio of book value of debt $(D)$ scaled by the book value of debt and the market value of equity $(E)$ :

$A D R_{t}=\frac{D_{t}}{D_{t}+E_{t}}$ 
where $D_{t}$ is the sum of current liabilities and long-term liabilities at time $t$ and $E_{t}$ is the market value of equity at time $t$ (computed as the number of outstanding shares multiplied by the market price). As in Welch (2004), our explanatory variables are the lagged $A D R$ and the $\operatorname{IDR}_{t, t+k}$. IDR does not adjust its leverage, i.e., it neither issues nor retires debt or equity. It is constructed to measure the extent to which market leverage ratios are expected to change in response to stock returns. By construction, IDR moves mechanistically with stock returns, and not with managerial capital structure decisions. Consistent with Welch (2004) notation, the IDR is:

$$
I D R_{t, t+k}=\frac{D_{t}}{E_{t} \cdot\left(1+x_{t, t+k}\right)+D_{t}}
$$

where $D_{t}$ and $E_{t}$ are as defined above, $x_{t, t+k}$ is the stock return from $t$ to $t+k$ net of any dividend, $\epsilon_{t}$ is a random error, and $\mathrm{k}$ is the horizon measured in years.

Hence, the basic regression equation in Welch (2004) is:

$$
A D R_{t+k}=\alpha_{0}+\alpha_{1} \cdot A D R_{t}+\alpha_{2} \cdot I D R_{t, t+k}+\epsilon_{t}
$$

As in Welch (2004), perfect readjustment implies that $\alpha_{1}=1, \alpha_{2}=0$, while perfect inertia suggests $\alpha_{1}=0, \alpha_{2}=1$. As robustness checks, we also perform the analysis separately on short-term debt, long-term debt, and bank debt.

Under the hypothesis of optimizing behavior and zero adjustment costs, the readjustment hypothesis reflects a target that managers wish to achieve each period. On the other hand, the inertia (non-readjustment) hypothesis implies that any change in leverage between $t$ and $t+k$ is due to the stock return over the period. We estimate equation (3) twice, with and without an intercept. When we include the intercept $\alpha_{0}$, it 
captures a constant target debt ratio. If firms manage their capital structure to maximize the advantage of debt for the shareholders, then the coefficient on ADR should be unity. On the other hand, if debt ratios are driven mechanistically by stock returns, then the coefficient on IDR should be unity.

Since our focus is on the dynamics of a firm's capital structure choice, we express the capital structure adjustment in equation (2) as follows. Leverage changes with new debt issues, debt retirements, coupon payments, and debt value changes. As a result, corporate debt can be expressed as:

$D_{t+k}=D_{t}+T D N I_{t, t+k}$

where TDNI stands for total debt net issuing activity. As in Welch (2004), we define TDNI as the difference in total debt value between $t+k$ and $t$. Similarly, corporate equity changes with stock returns (net of dividends), and new equity issues net of equity repurchases. Consequently, corporate equity can be expressed as:

$$
E_{t+k}=E_{t} \cdot\left(1+x_{t, t+k}\right)+E N I_{t, t+k}
$$

where ENI reflects a firm's net equity issuing and stock repurchasing activity. ENI is then defined as the difference in total equity value between $t+k$ and $t$ without return and dividend effects. Under this definition, actual debt ratios can be expressed as:

$$
A D R_{t, t+k}=\frac{D_{t+k}}{D_{t+k}+E_{t+k}}=\frac{D_{t}+T D N I_{t, t+k}}{D_{t}+T D N I_{t, t+k}+E_{t} \cdot\left(1+x_{t, t+k}\right)+E N I_{t, t+k}}
$$

\section{Descriptive Statistics}

Table 1 presents summary statistics of basic variables after modifications to address outliers as follows. We trim the upper and lower two percentile of each variable's distribution in the normalized series. Using these criteria, we identify 1,212 firm-year 
observations for the one-year regression and 612 for the 5-year regressions, covering corporate financing behaviour from 1989 to 2003.

On average, Omani companies have a total accounting assets of RO 40 million, with around $47 \%$ of the assets being short-term. ${ }^{1}$ These assets are employed to earn an average RO 8.1 million in revenue. The mean market value of sample firms is about 1.33 times accounting assets. However, the median market value is much smaller than the book value of assets. Similarly, the median market value is considerably smaller than the mean market value. The actual debt ratio is around $48 \%$, financed mostly through bank loans. ${ }^{2}$ Short-term debt exceeds long-term debt ratio during the period under investigation. The standard deviation for short-term debt ratio similarly exceeds that for long-term debt.

The summary statistics of Table 1 show the importance of the dynamic components of debt ratios. During the period of study, the average sample firm achieves stock return of around $1.5 \%$ and pay out $0.9 \%$ in dividends. This is significantly lower than the $8.8 \%$ return reported in Welch (2004) for US firms. A difference also exists for the stock price induced capitalization change which is about $0.1 \%$ in Oman compared to $7.0 \%$ in the US. However, a different pattern exists for issuing activity in Oman where Omani firms seem to issue more debt and equity than firms in the US. On average, Omani firms issue approximately $6.6 \%$ (3.7\% for the US) in debt and $6.3 \%(2.4 \%$ for the US) in equity. This suggests that Omani firms are quite active issuers. As a result, issuing activity may

\footnotetext{
${ }^{1}$ We did not inflation-adjust book values because the rate of inflation in Oman during the sample period is low.

${ }^{2}$ This is much higher than the $29.8 \%$ reported by Welch (2004) for the US.
} 
potentially be large enough to counteract a substantial part of stock return influence on capital structure choice. ${ }^{3}$

\section{Insert Table 1 here}

To examine whether stock returns can explain debt ratio dynamics, we follow Welch's approach. We first sort all firms by calendar year. Then we sort by sales decile to control for size. Then we allocate firms into 10 bins on the basis of their net stock return performance where we keep a roughly equal number of firms in each decile. The header rows in Table 2 report the median net stock returns for each decile. The first three rows report actual capital structure relevance of debt ratio dynamics. The "ending ADR" rows suggest that there is a large spread of resulting debt ratios across firms having recently experienced different rates of return. Over a one year horizon, the worst stock performers end up with an actual debt ratio of $60.4 \%$ whereas firms with the best stock performance end up with an actual debt ratio of $43 \%$. Over five years, firms that have underperformed the MSM by $19 \%$ end up with an actual debt ratio of $58.7 \%$, while firms that have outperformed the MSM by $75 \%$ end up with an actual debt ratio of $46.1 \%$.

\section{Insert Table2 here}

The "starting ADR" rows demonstrate that over one year the worst stock performers have lower starting debt ratios than the best stock performers. A similar pattern is exhibited over the 5-year horizon. This suggests that there is a correlation between debt ratios and stock performance.

\footnotetext{
${ }^{3}$ We found that firms did try to offset the mechanistic effect of stock return surprises but did so slowly. Results are not reported but available on request.
} 
The "implied IDR" rows show the impact of stock returns on starting debt ratios. Over one year, firms that have underperformed the MSM end up with higher implied debt ratio relative to firms that have outperformed the stock market. However, the opposite pattern appears in the 5-year horizon. This means that over one year firms with poor stock performance have high implied debt ratios which are then reversed in the 5-year horizon. Data rows four to eight present corporate debt issue and dividend activity, while the ninth row reports equity growth, all scaled by firm size. The results indicate that the majority of firms are quite active with respect to their capital structures. Over one year, firms respond to poor stock performance with more equity issuing activity and to good performance with more debt issuing activity. ${ }^{4}$ This is opposite to what Welch reports for the US. However, the relationship is not clear over the 5-year horizon in terms of debt issuing. Over five years, firms issue less equity regardless of stock return performance. The seventh row shows a negative relationship between stock performance and "activist equity expansion" over an annual horizon. This relationship disappears over the 5-year horizon where equity expansion contracts regardless of stock returns.

The eighth row investigates whether firms intentionally expand or contract in response to stock return performance. Over both annual and 5-year horizons, firms appear to contract regardless of stock return performance. However, this contraction is larger for firms with good stock performance compared to firms with poor performance over a five year period. As an exception, the best decile of stock price performers do engage in some active expansion, approximately, $45.8 \%$ of their firm value. This suggests that firms do take countermeasures to offset the impact of stock return surprises. The last

\footnotetext{
${ }^{4}$ This implies that firms in our sample do try to counteract the mechanical influence of stock returns. However, the relationship is not strong. See also footnote (3).
} 
row in Table 2 shows a positive association between induced equity growth and stock performance over both annual and 5-year horizon. For instance, firms with good stock performance have more stock return induced equity growth compared to firms with poor stock performance.

In summary, most MSM firms are quite active in their capital structure decisions. Firms make quite frequent approaches to the public and private financial markets. Our results show that firm's stock returns induce some corporate issuing activity and it seems that managers use issuing activity to counteract some of the mechanistic effect of stock returns. Stock return induced equity growth moves in tandem with stock return performance.

\section{Estimation Results}

Table 3 presents the empirical results computed using the basic regression equation (3). To avoid overstating significance levels by pooling the data over time, we employ the Fama and MacBeth (F-M) (1973) regression approach. Under this methodology, we first run yearly cross sectional regressions. We then report the mean coefficient estimates across time and use the time series standard deviation of the slopes in the year-by-year regressions to compute standard errors. The main advantage of this approach is that it circumvents the problems caused by heteroscedasticity and correlation of residuals across firms (Lipson and Mortal (2008)). Fama and French (2002, p. 3) describe F-M as "a simple way to obtain robust standard errors that capture whatever contributes to the precision of the average slopes". Another advantage of this approach is that it enables us to have a large number of data points. This increases the precision of the slopes and reduces their year-by-year volatility (Fama and French (1998)). However, as Fama and 
French (1998) note, this approach suffers from the problem that the sample autocorrelation of the slopes is imprecise. They account for the autocorrelation of the regression slopes by requiring a $t$-statistic of around three to infer reliability. In this study, we closely follow this approach. We are also concerned that the regressions may suffer from extreme observations. We winsorize the distributions at the $2^{\text {nd }}$ and $98^{\text {th }}$ percentile for variables with extreme values, consistent with Welch (2004).

Panel A of Table 3 reports the results without a constant, and thus does not allow for a constant target debt ratio. For the one year horizon, all panels show that the $\operatorname{IDR}_{t, t+k}$ better explains the predicted $\mathrm{ADR}_{\mathrm{t}+\mathrm{k}}$ than does the lagged $\mathrm{ADR}_{\mathrm{t}}$. The coefficients on $\mathrm{IDR}_{\mathrm{t}, \mathrm{t}+\mathrm{k}}$ are in the range of $50 \%$ to $70 \%$, whereas the range for $\mathrm{ADR}_{\mathrm{t}}$ is $26 \%$ to $41 \%$. This suggests that a large fraction of the time variation in the level of leverage stems from movements in the stock returns. Over one year, an average firm allows its debt ratio to drift by around $62 \%$ with stock returns. The average firm show some tendency to move back towards its past debt ratio. Still, the influence of stock returns through IDR dominates the effects of readjustments. Over all horizons, the coefficient on ADR is about half the size of the IDR coefficient, suggesting that the impact of stock returns is twice as large as the effects of readjustments. Now turning to the diagnostics of the regression estimates, the adjusted $\mathrm{R}^{2}$ is strong in all cases. However, it generally exhibits an inverse relation with the model horizon. The adjusted $\mathrm{R}^{2}$ is $93 \%$ for the 1-year regression, while it is $88 \%, 85.5 \%, 82 \%$ and $84 \%$ for the two years, three years, four years, and five years, respectively.

\section{Insert Table 3 here}

Nevertheless, if we compare our results with those of Welch we see that the impact of stock returns in Oman is much less than that for the US. In a similar vein, Omani 
firms are more inclined to adjust their capital structure to their old debt ratios relative to firms in the US.

Panel B of Table 3 presents the results of estimating equation (3) including an intercept. This panel demonstrates similar results to the results obtained in Panel A. The coefficients on ADR suggest that firms have some tendency to revert to their old debt ratios, though the inclusion of the constant reduces the estimated ADR coefficients relative to Panel A. However, the coefficients on IDR still exert considerably more influence on firms' debt ratios than does ADR. Additionally, the intercepts are relatively similar in magnitude and exhibit a positive association with the model horizon. This implies that firms show marginal increases in debt ratios over the sample period. In summary, all panels show that the $\operatorname{IDR}_{\mathrm{t}, \mathrm{t}+\mathrm{k}}$ lines up better with the predicted $\mathrm{ADR}_{\mathrm{t}+\mathrm{k}}$ than does the lagged $\mathrm{ADR}_{\mathrm{t}}$. This suggests that a large fraction of the time variation in the level of leverage stems from movements in the stock returns, as opposed to active financial management. This does not mean that firms do not try to rebalance. In fact, firms in our sample show some tendency to return to their old debt ratios, and this tendency is more pronounced for Oman that it is for US firms. However, the impact of stock returns dominates the effects of adjustments.

\section{Conclusion}

We examine whether capital structure changes are driven by stock price movements for Omani companies listed on MSM. Using data for Oman provides several advantages. First, the data avoid the complexity of tax systems faced by previous studies, and as a result may help us to provide clearer results on the importance of debt in financing firms in a personal tax free environment. Second, Oman has unique financing arrangements 
that are characterized by high leverage and high reliance on bank debt, which should alleviates the agency problems by forcing managers to pay out the firm's free cash flow.

Our main findings are as follows. First, we find strong evidence that equity price shocks have a primary effect on corporate capital structure dynamics. Second, the average firm in our sample shows some tendency to rebalance their capital structure in response to shocks in the market value of equity. However, stock returns exert more influence on the market leverage ratio compared to the effects of rebalancing.

There are some important differences between the findings of this study and Welch (2004). First, the impact of stock returns is less pronounced compared to the US. Second, Omani firms have a higher inclination to readjust their capital structure. Third, in contrast to Welch, we find short-term debt issuing activity is the most capital structure relevant corporate activity. Our conclusion is that stock price effects are more important in explaining leverage ratios than several factors previously identified in the capital structure literature.

In sum, the empirical results highlight the distinctive features of the Omani business environment and could therefore be of particular value for policy makers. For example, the apparent narrow choice over sources of finance - primary bank loans - for corporate investment should be of interest to policy makers as expansion of these sources may contribute to economic growth. Second, the limited size of bond market in Oman constrains firms' choices over sources of financing, forcing them to take loans from banks. The development of a market for corporate bonds would give firms more room in choosing sources of financing. Thus polices that are concerned with the development of the bond market may need to be considered if firms are to be encouraged to optimize their capital structure. 


\section{References}

Al-Yahyaee, K. (2006) Capital Structure and Dividend Policy in a Personal Tax Free Environment: The Case of Oman. Unpublished PhD. Thesis, The University of New South Wales, Sydney, Australia.

Al-Yahyaee, K., Pham, T. and Walter, T. (2008) Ex-Dividend Day Behavior in the Absence of Taxes and Price Discreteness, International Review of Finance, 8, 103-123.

Baker, M., and Wurgler, J. (2002) Market Timing and Capital Structure, Journal of Finance, 62, 1-32.

Baltagi, B. (2005) Econometric Analysis of Panel Data. New York: John Wiley and Sons.

Booth, L., Aivazian, V., Demirguc-Kunt, A. and Maksimovic, J. (2001) Capital Structures in Developing Countries, Journal of Finance, 56, 87-130.

Cai, J. and Zhang, Z. (2006) Capital Structure Dynamics and Stock Returns, Singapore Management University Working Paper.

Denis, D., and Mihov, V. (2003) The Choice Among Bank Debt, Non-Bank Private Debt, and Public Debt: Evidence from New Corporate Borrowings, Journal of Financial Economics, 70, 3-28.

Fama, E., and French, K. (1998) Taxes, Financing Decisions, and Firm Value, Journal of Finance, 53, 819-843.

Fama, E., and French, K. (2002), Testing Tradeoff and Pecking Order Predictions about Dividends and Debt, Review of Financial Studies, 15, 1-33.

Fama, E., and J.D. MacBeth, J.D. (1973) Risk, Return and Equilibrium: Empirical Tests, Journal of Political Economy, 81, 607-636. 
Faulkender, M., and Petersen, and M. (2006) Does the Source of Capital Affect Capital Structure?, Review of Financial Studies, 19, 45-79.

Flannery, M., and Rangan, K. (2006) Partial Adjustment toward Target Capital Structures, Journal of Financial Economics, 79, 469-506.

Frank, M., and Goyal, V. (2009) Capital Structure Decisions: Which Factors are Reliably Important?', Financial Management, 38, 1-37.

Graham, J. (1996) Debt and the Marginal Tax Rate, Journal of Financial Economics, 41, 41-73.

Graham, J. (2000) How Big are the Tax Benefits of Debt?, Journal of Finance, 55, 1901-1941.

Graham, J., M. Lemmon, and Schallheim, J. (1998) Debt, Leases, Taxes, and the Endogeneity of Corporate Tax Status, Journal of Finance, 53, 131-161.

Hovakimian, A. (2006) Are Observed Capital Structures Determined by Equity Market Timing?, Journal of Financial and Quantitative Analysis, 41, 221-243.

Hovakimian, A., Opler, T. and Titman, S. (2001) The Debt-equity Choice, Journal of Financial and Quantitative Analysis, 36, 1-24.

Huang, R., and Ritter, J. (2009) Testing Theories of Capital Structure and Estimating the Speed of Adjustment, Journal of Financial and Quantitative Analysis, 44, 237271.

Jalilvand, A., and Harris, R. (1984) Corporate Behavior in Adjusting to Capital Structure and Dividend Targets: An Econometric Study, Journal of Finance, 39, $127-145$.

Kayhan, A., and Titman, S. (2007) Firms' Histories and Their Capital Structure, Journal of Financial Economics, 83, 1-32. 
Leary, M., and Roberts, M. (2005) Do Firms Rebalance Their Capital Structures?, Journal of Finance, 60, 2575-2619.

Lemmon, M., Roberts, M., and Zender, J. (2008) Back to the Beginning: Persistence and the Cross-Section of Corporate Capital Structure, Journal of Finance, 63, 15751608.

Lipson, M., and Mortal, S. (2008) Capital Structure Decisions and Equity Market Liquidity, University of Virginia Working Paper.

Mackie-Mason, P. (1990) Do Taxes Affect Corporate Financing Decisions?, Journal of Finance, 44, 1471-1493.

Myers, S. (1984) The Capital Structure Puzzle, Journal of Finance, 39, 575-592.

Rajan, R., and Zingales, L. (1995) What do we know about capital structure? Some Evidence from International Data, Journal of Finance, 50, 1421-1460.

Share-Holding Guide of MSM Listed Companies. Muscat Securities Market, 1989 2005, Muscat, Oman.

Titman, S., and Tsyplakov, S. (2007) A Dynamic Model of Optimal Capital Structure, Review of Finance, 11, 401-451.

Welch, I. (2004), Capital Structure and Stock Returns, Journal of Political Economy, 112, 106-131.

Welch, I., and Hoberg, G. (2002) What Do Book Values of Equity Mean?, Yale University Working Paper.

Xu, Z. (2007), Do Firms Adjust Toward a Target Leverage Level?, Bank of Canada Working Paper No. 50. 


\begin{tabular}{|c|c|c|c|c|c|c|c|}
\hline Abbreviation & Description & Mean & $\begin{array}{l}\text { 1-Year } \\
\text { Median }\end{array}$ & $\begin{array}{l}\text { Std. } \\
\text { Dev. }\end{array}$ & Mean & $\begin{array}{l}\text { 5-Year } \\
\text { Median }\end{array}$ & $\begin{array}{l}\text { Std. } \\
\text { Dev. }\end{array}$ \\
\hline$A D R_{t}$ & Actual Debt Ratio & 48.1 & 49.0 & 26.3 & \multirow{9}{*}{42.2} & \multirow{9}{*}{39.7} & \multirow{9}{*}{24.8} \\
\hline$I D R_{t, t+k}$ & Implied Debt Ratio & 47.0 & 48.0 & 26.8 & & & \\
\hline$A D R^{C L}$ & Actual Debt Ratio; Current Liabilities Only & 29.5 & 24.6 & 21.7 & & & \\
\hline$A D R^{L T L}$ & Actual Debt Ratio: Long-term Liabilities Only & 18.6 & 13.4 & 18.9 & & & \\
\hline$A D R^{B L}$ & Actual Debt Ratio: Bank Loan Only & 36.5 & 20.9 & 43.0 & & & \\
\hline$C A$ & Amount of Current Assets in (million Omani Rial ${ }^{5}$ ) & 19.20 & 2.32 & 144.10 & & & \\
\hline LTA & Amount of Long-term Assets in (million Omani Rial) & 21.33 & 2.49 & 97.05 & & & \\
\hline$E_{t}+D_{t}$ & Market values in (million Omani Rial) & 53.91 & 8.32 & 387.63 & & & \\
\hline \multirow[t]{2}{*}{ Rev } & Revenue in (million Omani Rial) & 8.11 & 2.41 & 20.33 & & & \\
\hline & Normalized by Market Value and Winsorized & & & & & & \\
\hline$T D N I_{t, t+k}$ & Net Debt Issuing & 6.6 & 3.0 & 16.0 & 5.3 & 12.3 & 60.8 \\
\hline$E N I_{t, t+k}$ & Net Equity Issuing w/o Dividends & 6.3 & 0.0 & 15.2 & -10.6 & 4.5 & 88.5 \\
\hline$T D N I_{t, t+k}+E N I_{t, t+k}$ & Debt and Equity Issuing & 14.2 & 4.6 & 32.4 & -9.7 & 27.5 & 140.8 \\
\hline $\operatorname{Divt}, t+k=\left(r_{t, t+k}-x_{t, t+k}\right) \cdot E_{t}$ & Dividends & 0.9 & 0.0 & 1.7 & 2.2 & 0.8 & 4.0 \\
\hline$E N I_{t, t+k}-\operatorname{Div}_{t, t+k}$ & Activist Equity Expansion & 5.0 & 0.0 & 15.8 & -13.0 & 3.3 & 90.4 \\
\hline$T D N I_{t, t+k}+E N I_{t, t+k}-D i v_{t, t+k}$ & Activist Total Expansion & 12.7 & 3.5 & 33.1 & -12.2 & 24.8 & 143.1 \\
\hline$r_{t, t+k} \cdot E_{t}$ & Total Return in Omani Rial & 1.5 & 0.0 & 13.5 & 2.0 & 1.6 & 13.9 \\
\hline$X_{t, t+k . .} E_{t}$ & Induced Equity Growth & 0.1 & 0.01 & 12.7 & 4.4 & 2.8 & 14.2 \\
\hline
\end{tabular}

The sample consists of all publicly listed firms at the MSM from 1989 to 2003. Firm years with missing data on book value of debt or market value of equity are excluded. There are 1,212 firm-year observations in the one-year panel and 612 firm-year observations in the five-year panel. Firms are normalized by firm value (book value of debt plus market value of equity) and then winsorized at the $2^{\text {nd }}$ and $98^{\text {th }}$ percentiles. Variables are expressed in percentages unless otherwise indicated.

\footnotetext{
${ }^{5}$ Omani Rial is worth around \$2.6.
} 
TABLE 2. Corporate activity, equity growth, and capital structure, classified by stock returns (year-adjusted and sales adjusted)

A: Sort by Calendar Year, Sales, One Year Net Stock Returns.

\begin{tabular}{|c|c|c|c|c|c|c|c|c|c|c|}
\hline Sort Criterion, Net Return $(t, t+1)$ & -63 & -30 & -16 & -6 & -1 & 0 & 7 & 21 & 45 & 198 \\
\hline Ending $\mathrm{ADR}_{\mathrm{t}+1}$ & 60.4 & 50.2 & 48.1 & 49.7 & 49.7 & 55.4 & 45.0 & 50.4 & 42.1 & 43.0 \\
\hline Return Induced IDR $\mathrm{I}_{\mathrm{t}, \mathrm{t}+1}$ & 67.2 & 50.2 & 46.0 & 49.5 & 48.8 & 52.4 & 41.7 & 47.3 & 38.4 & 38.6 \\
\hline Net Equity Issuing, ENI ${ }_{t, t+1}$ & 3.6 & 2.2 & -1.9 & -3.2 & 0.2 & -0.2 & 23.3 & -0.7 & 0.3 & -17.6 \\
\hline Dividends, DIV ${ }_{t, t+1}$ & 1.0 & 1.4 & 3.9 & 1.3 & 1.1 & 1.8 & 3.6 & 2.8 & 4.1 & 2.3 \\
\hline Activist Equity Expansion (ENI-DIV) & 2.6 & 0.9 & -5.8 & -4.5 & -0.9 & -2.0 & -26.9 & -3.5 & -3.8 & -19.9 \\
\hline
\end{tabular}

\begin{tabular}{|c|c|c|c|c|c|c|c|c|c|c|}
\hline \multicolumn{11}{|c|}{ Panel B: Sort by Calendar Year, Sales, 5-Year Net Stock Returns. } \\
\hline Sort Criterion, Net Return $(\mathrm{t}, \mathrm{t}+5)$ & -19 & -9 & -3 & 0 & 5 & 10 & 15 & 23 & 36 & 75 \\
\hline Starting $\mathrm{ADR}_{\mathrm{t}}$ & 35.6 & 32.5 & 36.2 & 43.9 & 41.3 & 46.7 & 42.9 & 45.8 & 57.6 & 58.4 \\
\hline Net Debt Issuing, TDNI ${ }_{t, t+5}$ & -23.0 & 5.3 & 9.7 & 7.7 & 6.0 & -1.2 & 11.6 & -17.0 & -42.4 & -2.9 \\
\hline Net Equity Issuing, ENI $\mathrm{t}, \mathrm{t}+5$ & -98.6 & -70.7 & -43.8 & -18.4 & -5.7 & 9.5 & 0.4 & -71.2 & -145.8 & 52.4 \\
\hline Dividends, DIV ${ }_{t, t+5}$ & 5.0 & 2.5 & 2.4 & 3.7 & 2.3 & 2.7 & 2.3 & 1.7 & 10.9 & 3.8 \\
\hline Induced Equity Growth, $\mathrm{X}_{\mathrm{t}, \mathrm{t}+5}$ & -32.6 & -9.9 & -3.4 & 0.4 & 2.7 & 4.5 & 6.6 & 14.9 & 24.5 & 39.6 \\
\hline
\end{tabular}

All variables are medians and are expressed in percentages. Firms are sorted first by year, then by sales decile, and then allocated to deciles based on their stock return rank (within each group of 10 firms). In each panel, the $4^{\text {th }}$ rows through the $9^{\text {th }}$ rows are normalized by firm size. Other rows are not normalized. In panel A, there are between 100 and 120 observations per decile; in panel B, between 50 and 65 . 
TABLE 3. Fama-MacBeth regressions predicting $\mathrm{ADR}_{t+k}$ with $\mathrm{ADR}_{t}$ and $\mathbf{I D R}_{t, t+k}$

Panel A: Without Intercept

\begin{tabular}{|c|c|c|c|c|c|c|c|c|c|}
\hline Horizon $k$ & con. & $\mathrm{ADR}_{\mathrm{t}}$ & $\mathrm{IDR}_{\mathrm{t}, \mathrm{t}+\mathrm{k}}$ & s.e.c & s.e.ADR & s.e.IDR & Adjusted $\mathrm{R}^{2}(\%)$ & $\mathrm{N}$ & $\mathrm{T}$ \\
\hline 1 Year F-M & & 26.3 & 62.4 & & 3.91 & 3.90 & 93.0 & 1212 & 14 \\
\hline 2 Year F-M & & 37.9 & 61.5 & & 5.66 & 5.67 & 88.0 & 1049 & 13 \\
\hline 3 Year F-M & & 34.7 & 62.4 & & 6.74 & 6.69 & 85.5 & 896 & 12 \\
\hline 4 Year F-M & & 40.9 & 50.7 & & 7.73 & 7.70 & 82.0 & 750 & 11 \\
\hline 5 Year F-M & & 28.5 & 69.3 & & 4.98 & 4.86 & 84.0 & 612 & 10 \\
\hline \multicolumn{10}{|c|}{ Panel B: With Intercept } \\
\hline Horizon $k$ & & $\mathrm{ADR}_{\mathrm{t}}$ & $\mathrm{IDR}_{\mathrm{t}, \mathrm{t}+\mathrm{k}}$ & & s.e.ADR & s.e.IDR & Adjusted $\mathrm{R}^{2}(\%)$ & $\mathrm{N}$ & $\mathrm{T}$ \\
\hline 1 Year F-M & 9.2 & 15.0 & 68.3 & 0.84 & 3.86 & 3.76 & 71.7 & 1212 & 14 \\
\hline 2 Year F-M & 15.3 & 18.8 & 53.6 & 1.18 & 5.44 & 5.26 & 53.3 & 1049 & 13 \\
\hline 3 Year F-M & 18.9 & 19.1 & 46.4 & 1.40 & 6.30 & 6.13 & 44.7 & 896 & 12 \\
\hline 4 Year F-M & 24.0 & 16.4 & 41.2 & 1.61 & 7.02 & 6.78 & 35.3 & 750 & 11 \\
\hline 5 Year F-M & 21.1 & 13.4 & 48.3 & 1.77 & 4.70 & 4.66 & 37.5 & 612 & 10 \\
\hline
\end{tabular}

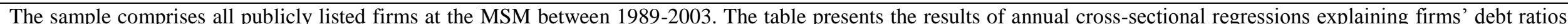

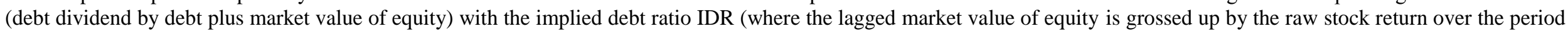

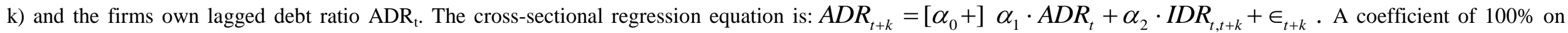
$\mathrm{ADR}_{\mathrm{t}}$ indicates perfect readjustment. On the other hand, a coefficient of $100 \%$ on IDR $_{\mathrm{t}, \mathrm{t}+\mathrm{k}}$ indicates perfect lack of readjustment. Fama and MacBeth report means (across years)

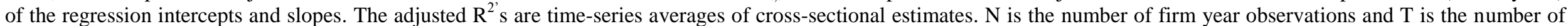
cross-sectional regressions. 